\title{
PRESERVING WILDLIFE AND NATURAL AREAS
}

This Blue Jay has three articles telling how conservation problems ar being tackled in the United States and India and here in Canada.

There are also three letters especially concerned with conservationDot Wade revisits the wonderful Wascana Marsh in Regina; Ernie Kuyt tell of legislation to preserve unspoiled woodlands at Fort Smith; Herb Mouldin: urges Saskatchewan to be the first province to protect non-game as well a game species.

Having such problems in mind I was encouraged to find, on a recent visi to Toronto, that damage may be repaired and that "true conservation" on very impressive scale may take place even where the human population i increasing explosively. Toronto is a big city containing nearly one-tenth 0 : all the people of Canada, more than twice the number living in all Saskatche wan. I knew that urban sprawl on such a scale was destroying natural areas including the beautiful Don Valley described by E. T. Seton in his Two Littl Savages. Mr. C. Sauriol, of the Metropolitan Toronto and Region Conservatior Authority and of the Nature Conservancy of Canada took me on a quick tous of some of the conservation projects which are now restoring nature and natural beauty to much of Toronto.

The Authority was established in 1957 to conserve the renewable natura resources in a thousand square miles of the watershed of several rivers which pour down through the centre of Toronto. The plan required the purchasing of expensive property and the building of control dams and of concrete channels where property was too expensive to acquire as flood plains. In ten years 40 million dollars have been spent. Floods are controlled by an impressive telemetering of stream flow and precipitation data. Accompanying the flood control work is reforestation of important watershed areas, land use management, fish and wildlife management and conservation education programmes and recreation. Not all areas needed for reforestation could be acquired but this difficulty was largely overcome by encouragement of reforestation and some 5,000,000 trees have been planted on private land. Shrubs have also been planted and nest boxes for wood ducks and bluebirds have been erected.

Seven of the conservation areas have nature trails and it is said "many areas have been completely restored to their original pristine beauty and naturalness". The picnicking facilities have been much appreciated and some areas immediately came under heavy use. Over one million people have visited the 12 recreation areas. The success of the project has been greatly increased by many handsome donations of expensive property. For example, Robert and Signe McMichael gave their home, a 40 -acre property along the Humber, and their unique collection of Canadian art which is now visited by as many as 1700 persons on a single Sunday afternoon. This spring the Foundation demonstrated modern and old-time methods of sap collecting and maple syrup making. It was educational and highly successful with over 24,000 visitors.

In Albion Hills there is a conservation school which can accommodate 40 students at a time. During the regular school term class groups are taken in for five days of intensive conservation study. The Black Creek Pioneer Village is also educational. Its Dalziel Barn, 1809, is the oldest building but others including a Halfway House and a grist mill have been carefully restored. People in the village are dressed in pre-Confederation type clothing. It seems an unusual side development for the conservation project, but how very important it is to give our young an appreciation of our past and of our original environment for without interest and understanding they will see little need for conservation and for thought of the future. 